$1(28) / 2015$

\author{
Joanna Nowak \\ Elbląska Uczelnia Humanistyczo-Ekonomiczna \\ asianowakk@wp.pl
}

\title{
Kompetencje pedagogiczne studentów edukacji wczesnoszkolnej jednym z warunków zmiany rozwojowej uczniów
}

\section{Summary \\ Pedagogical competence of early-education students as one of the conditions for pupils' developmental change}

Teachers' work is subjected to constant evaluation by students, parents, other teachers, and society. High demands in the face of changing socio-cultural, educational reality require from teachers the continuous improvement of pedagogical competences. The article raises the question of teachers' competences acquired by the students of early school education during three years of studies. The scope and type of those competences determine pupils' developmental change. On the basis of surveys and interviews conducted on 50 students it is possible to formulate numerous conclusions. The most important one indicates that students are comprehensively prepared and gain pedagogical knowledge that allows them to treat pupils subjectively, encourage them to take part in discussions, and organize activities with appropriate methods and forms. Other areas of responsibility may be developed and improved in the course of work.

Słowa klucze: kompetencje pedagogiczne, zmiana rozwojowa, wspomaganie rozwoju, przygotowanie do zawodu nauczyciela

Keywords: pedagogical competence, developmental change, developmental support, becoming a teacher

Wspieranie rozwoju dzieci w procesie wczesnej edukacji jest wyrazem przyjęcia humanistycznej koncepcji człowieka, w której dominującą tendencją decydującą o działaniu jest proces samorealizacji i aktualizacji „własnych potencjalnych szans” (Kozielecki 1980: 260), czyli jednostkowy rozwój wszystkich zdolności, podejmowanie własnych, odpowiedzialnych decyzji, tworzenie siebie samego poprzez autonomiczne działanie, jednocześnie poprzez rozszerzanie wewnętrznego i zewnętrznego poznania odnajdujemy swoje miejsce w świecie (Śliwerski 2012: 263). Naukowa synteza wiedzy Józefa Górniewicza na temat samorealizacji, zdaniem Bogusława Śliwerskiego, „pozwoliła na wyodrębnienie między innymi pojęcia i uznanie, że jednostka dysponuje mechanizmami sprawczego wpływania na własny rozwój” (Śliwerski 2012: 263), a w myśl założeń konstruktywizmu „nadając znaczenie światu, sobie samym i naszemu stosunkowi do świata - tworzymy pewną konstrukcję, która realizuje się w ciągu naszego życia jako ciągle dokonujący się 
rozwój i nieustannie zmienia się mniej lub bardziej w procesie doświadczania i poznania" (Dauber 1997: 62). „Idea rozwoju” spełnia się poprzez konstrukcje tworzone w określonym kontekście, które zmieniają się i dalej mogą się zmieniać (Dauber 1997: 63). Ta perspektywa nie wyklucza innych czynników tak istotnych w rozwoju. Właściwości wrodzone jednostki, środowisko społeczno-kulturowe, w którym ona funkcjonuje, proces wychowania i aktywność własna wzajemnie warunkują i wyznaczają możliwości rozwojowe, ponieważ - jak uważa Lew Wygotski - ,indywidualna historia podmiotu jest ściśle związana z jego historią społeczną" (Wygotski 1978: 40).

Wraz z rozwojem dziecko zmienia rzeczywistość, reaguje na nią, tworzy związki treściowe między poznaniem, doświadczeniem i działaniem, „(..) wchodzi w stosunki z sytuacją nie bezpośrednio, ale za pośrednictwem drugiej osoby” (Wygotski 1978: 45). Tworzy konstrukty dzięki pomocy nauczyciela, którego Wygotski nazywa „pośrednikiem zewnętrznym". Pośredniczy, wspomaga, wspiera indywidualny, intelektualny rozwój, zainteresowania ucznia, jego aktywność w działaniach i relacje z innymi. Efektem takiej aktywności nauczyciela powinna być zmiana rozwojowa uczniów uzyskiwana w toku edukacji.

\section{Pojęcie zmiany rozwojowej}

Istotą rozwoju jest zmiana, ale wśród wielu psychologicznych koncepcji rozwoju dla niniejszych rozważań ważne są te, które zmiany rozwojowe traktują jako trwałe, nieodwracalne i autonomiczne. Osiągnięte poziomy (stany) organizacji wewnętrznej nie dają się odwrócić, a zapoczątkowane w przebiegu procesów rozwoju, w dłuższym czasie inicjują kolejne zmiany. Tworzy się w ten sposób struktura (układ relacyjny) psychicznej organizacji wewnętrznej jednostki, niezależna i autonomiczna. Niezależna i autonomiczna, ponieważ obejmuje proces indywidualnego rozwoju, spowodowany wewnętrznymi czynnikami tkwiącymi w danym układzie. Jednostka działa w kontekście i relacji z organizmem, ale też podejmuje różne relacje ze światem zewnętrznym, tworząc nowe układy, które wpływają na dalsze procesy zmian rozwojowych (Przetacznik-Gierowska, Tyszkowa 2003: 46-49). Jak pisze Dorota Klus-Stańska: „zmiana rozwojowa jest więc efektem wrażliwie budowanego stosunku między wymaganiami rozwoju dziecka a odpowiedzią otoczenia na ten rozwój" (Klus-Stańska 2009: 460). W takim podejściu do zmiany rozwojowej istotna jest reakcja otoczenia (rodziny, szkoły) na możliwości dziecka. Osiąganie kolejnych poziomów rozwoju przez dziecko w edukacji wczesnoszkolnej związane jest $\mathrm{z}$ warunkami uczenia się, jakie organizuje nauczyciel, jego sposobem stawiania zadań i wymagań, oczekiwań i wsparcia, którego udziela dziecku, a także z dawaniem swobody konstruowania własnego rozwoju, jednostce. Postawa nauczyciela i jego kompetencje pedagogiczne w dużym stopniu będą stanowiły o jakości zmian.

Współczesne teorie wyjaśniające procesy rozwoju i uczenia się dzieci dają możliwość wyboru podejścia i rozumienia zmiany rozwojowej. Przyjmując definicję zmiany rozwojowej za Klus-Stańską pominięto w opisie model behawiorystyczny, który zmiany rozwojowe dostrzega jako oddziaływanie środowiska zewnętrznego (nauczyciela) na jed- 
nostkę, zaplanowane, systematyczne i utrwalone za pomocą wzmocnień, pozytywnych i negatywnych.

W modelu interakcyjnym zakładano, że interpretowanie, modyfikowanie, rekonstruowanie informacji i doświadczeń w umyśle dziecka jest efektem zmiany rozwojowej i odpowiedzią dziecka na bodźce płynące z zewnątrz (Klus-Stańska 2009: 465).

W konstruktywizmie rozwojowym Piageta dziecko jest badaczem świata, a poprzez swoją w nim aktywność poznawczą tworzy wiedzę osobistą, weryfikuje przyjęte wcześniej hipotezy i nadaje tym hipotezom nowy konstrukt. „Uczenie się jest przedstawiane jako aktywna, eksploracyjna, samodzielna pod względem koncepcyjnym i decyzyjnym konstrukcja i rekonstrukcja umysłowych modeli rzeczywistości" (Klus-Stańska 2009a: 61). W toku takich doświadczeń i działań ucznia postawa nauczyciela ogranicza się do organizowania warunków środowiska do nauki, stosowania metod pobudzających aktywność dziecka, wspierania w rozwiązywaniu problemów. Zdaniem Brunera celem działania nauczyciela ,powinno być prowadzenie dziecka do samodzielnych odkryć.[...] Zalety metody polegającej na zachęcaniu do samodzielnych odkryć są dwojakie. Po pierwsze, materiał przyswojony w ten sposób staje się prawdziwą własnością dziecka, zintegrowaną częścią budowanej samodzielnie kultury wewnętrznej. [...] Po drugie, dokonanie samodzielnego odkrycia oraz związana z tym wiara we własne siły jest właściwą nagrodą za naukę" (Bruner 1971: 161-162). Takie podejście wymaga od nauczyciela innej wiedzy i umiejętności organizacji procesu kształcenia w stosunku do tradycyjnego, instytucjonalnie ograniczonego w czasie myślenia o wiodącej roli szkoły i nauczyciela w zdobywaniu wiedzy przez dzieci. Zmiana rozwojowa uczniów będzie efektem ich indywidualnej „zdolności do formułowania własnych hipotez, dostrzegania ich nietrafności i ich modyfikowania" (Klus-Stańska 2009: 467).

W opozycji do teorii indywidualizmu intelektualnego Piageta teoria Wygotskiego rozwój opisuje w szerokim kontekście społeczno-kulturowym. „Źródło rozwoju [...] tkwi w otoczeniu społecznym dziecka i w swej konkretnej postaci przejawia się w specyficznych stosunkach z eksperymentatorem, które określają całą sytuację, wymagającą narzędzi i wnoszą w nią aspekt społeczny” (Wygotski 1978: 45). Wygotski wierzył, że „prawdziwa edukacja nie polega na samym przyswojeniu określonej wiedzy lub umiejętności - polega na rozwoju umiejętności uczenia się dzieci, czyli ich umiejętności jasnego i kreatywnego myślenia, planowania i realizowania swoich planów oraz komunikowania swojego rozumienia na wiele sposobów" (Dolya 2007: 8). Swoboda myślenia, stawianie i weryfikacja hipotez to tezy opisane wcześniej przez Piageta, ale Wygotski poszerzanie możliwości umysłowych ucznia i efektywnego uczenia dostrzegał przede wszystkim w wykorzystaniu różnego rodzaju narzędzi i umiejętnym komunikowaniu się z otoczeniem społecznym. Uważał, że „narzędzia fizyczne i psychologiczne (znaki, symbole, schematy, modele, plany), umiejętnie wykorzystywane, rozwijają potencjał umysłowy dziecka, ale dopiero w połączeniu z narzędziami kulturowymi (np. językiem) szybciej i skuteczniej analizują rzeczywistość, rozwijają obszary intelektualne i nowe cechy psychologiczne" (Dolya 2007: 8-9). W swoich pracach akcentował „współzależność między myślą a tym bardziej uniwersal- 
nym narzędziem kulturowym, jakim jest język” (Dolya 2007: 9). „O ile na początku rozwoju występuje działanie niezależne od słowa, to na jego końcu jest słowo, które staje się działaniem" (Wygotski 1978: 146). Kontekst społeczno-kulturowo-edukacyjny wyzwala rozwój wyższych funkcji mentalnych, jak: uwaga, pamięć, myślenie symboliczne.

We wspomaganiu rozwoju mowy, bogatego języka za najważniejszą uważał Wygotski rolę nauczyciela/dorosłego. Szkoła powinna być „,miejsce spotkania dziecka i osoby dorosłej" (Dolya 2007: 9), powinna wspierać proces rozwoju, stymulować, proponować nowe działania, w których dziecko w interakcji z rówieśnikami będzie realizowało zadania i aktywnie przekraczało swoje możliwości. Wygotski zdefiniował poziom potencjalnego rozwoju dziecka, granicę wyzwania jako sferę najbliższego rozwoju, inaczej „różnicę między rzeczywistym poziomem rozwoju określonym poprzez niezależne rozwiązywanie problemów i poziomem potencjalnego rozwoju określonym poprzez rozwiązywanie problemów pod okiem dorosłych lub we współpracy z bardziej zdolnymi rówieśnikami” (Wygotski 1978: 86).

Znaczeniem procesów poznawczych w rozwoju i związkiem ich z kształceniem zajmuje się współcześnie Bruner. W opracowanej przez niego koncepcji rozwój człowieka rozumiany jest jako „zdolność do zdobywania, transformowania i przechowywania wiedzy dla własnych celów” (Jaworska, Leppert 2001: 278). Tę zdolność Bruner łączy z kształceniem, czyli umiejętnością samodzielnego dokonywania odkryć. Zdaniem Brunera podkreślenie wagi samodzielnego odkrywania wiedzy pozwala „zapoznać się $\mathrm{z}$ różnymi sposobami rozwiązywania zagadnień, przetwarzaniem informacji w sposób umożliwiający pełniejsze ich wykorzystanie (...)" (Bruner 1971: 117). Podmiot w relacji kształcenie - rozwój musi być aktywny, a zdobywaną wiedzę odnosi do istniejącego już, utworzonego wewnętrznego układu odniesienia i na tej podstawie konstruuje nowe informacje, gromadzi je i przekształca. Ten wewnętrzny układ/model świata umożliwia jednostce formułowanie i weryfikowanie hipotez oraz wnioskowanie. Wychodzenie poza dostarczone informacje, tworzenie hipotez, oryginalne rozwiązywanie problemów jest warunkiem rozwoju twórczej osobowości, warunkiem zmiany rozwojowej (Jaworska, Leppert 2001: 281). Zmiana rozwojowa będzie zatem efektem właściwie realizowanego procesu kształcenia, w którym istotna jest motywacja wewnętrzna i aktywność jednostki. „Jednym z warunków obudzenia w uczniu prawdziwej aktywności poznawczej jest uwolnienie go od bezpośredniej presji zewnętrznej w postaci kar i nagród” (Bruner 1971: 117). Odpowiedni styl nauczania, taki, który będzie wzmacniał nastawienie do dokonywania odkryć, a także „materiał zorganizowany w kategoriach zgodności z osobistymi zainteresowaniami i według własnych struktur poznawczych, ma największe szanse na to, by być łatwo dostępnym pamięciowo" (Bruner 1971: 128-129), pozwoli stawiać hipotezy i przy pomocy odpowiednich technik weryfikować je (Jaworska, Leppert 2001: 282-284). Związek między kształceniem a rozwojem J. Bruner zawarł w hipotezie: „Każde dziecko w dowolnej fazie jego rozwoju można skutecznie nauczyć dowolnego przedmiotu w sposób intelektualnie uczciwy" (Jaworska, Leppert 2001: 284). Badania naukowe prowadzone przez psychologów, neurobiologów, psychiatrów (np. Farah, Danese, Hood) nad rozwo- 
jem umysłowym dzieci przez dwie ostatnie dekady, pozytywnie weryfikują tę hipotezę. Nowe technologie obrazowania pozwalają naukowcom śledzić rozwój mózgu w czasie dzieciństwa aż do dorastania. Badania Farah, dyrektor Ośrodka Neurologii Uniwersytetu w Pensynwalii wykazały, że zakres doświadczeń z dzieciństwa ma wpływ na rozwój mózgu. W ciągu 20 lat badała życie rodzinne (proces wychowania) i dokonywała skanowania mózgu 64 uczestników badań. Badania rozpoczęto, kiedy dzieci miały cztery lata, osiem lat oraz między 17 a 19 rokiem życia. Rozwój kory mózgowej w wieku 17-19 lat był mocno skorelowany ze stymulacją poznawczą dziecka w wieku czterech lat. Czynniki takie, jak wychowanie w każdym wieku i stymulacja w wieku ośmiu lat, nie miały tak dużego wpływu. Stymulacja funkcji poznawczych (przez rodziców, nauczycieli) u dzieci w wieku czterech lat jest kluczowym czynnikiem, który decyduje o rozwoju mózgu np. 15 lat później. Wczesne dzieciństwo w otoczeniu kolorowych książek, gier i zabawek edukacyjnych sprzyja rozwojowi pamięci sensorycznej, przetwarzaniu słów, ogólnej wiedzy o świecie. Danese, wykładowca w Instytucie Psychiatrii Kings College w Londynie, twierdzi, że środowisko rodzinne i szkolne powinno dostarczać dzieciom doświadczeń, które mają wpływ na rozwój mózgu, umożliwić im rozwijanie umiejętności poznawczych, społecznych, emocjonalnych. Zapewnienie przez rodziców poczucia bezpieczeństwa, osobistych relacji z dziećmi może stworzyć podstawy do rozwoju innych zdolności czy umiejętności, np. podejmowania decyzji u nastolatków (Jho, The Guardian 10/2012). O braku wpływu rodziców na wychowanie dzieci pisze Szlendak, powołując się na badania Turkheimera, psychologa z Uniwersytetu w Wirginii, który w 2000 roku sformułował trzy prawa genetyki zachowania dowodząc, że wpływ rodziców na rozwój cech dziedzicznych dziecka jest znikomy, a procesy wychowawcze w rodzinie nie przynoszą oczekiwanych rezultatów, zachowanie i rozwój zależy od swoistego środowiska jednostki, nie od wychowania. Większe znaczenie w rozwoju, procesie wychowania dziecka ma środowisko rówieśnicze, jest ono jednak podporządkowane naturze, tzn. hamuje lub wzmaga cechy behawioralne. „Dzieci wychowują się same, uczestnicząc w rówieśniczych rozgrywkach, a jedyne co rodzice mogą uczynić dla rozwoju swoich pociech, to wnieść do ich bagażu genetycznego jak najlepszą pulę genów i dbać, by przeżyły w dobrym zdrowiu" (Szlendak 2011: 2) - do takiego wniosku doszła autorka teorii socjalizacji grupowej Judith Rich Harris, dodając, że rodzice są zbędni, ponieważ to nie oni wychowują dzieci. Takie podejście sprowadza analizę rozwoju człowieka i obecności w nim procesu wychowania w rodzinie, szkole, do dwóch czynników, jakimi są: geny i środowisko rówieśnicze. Wszystkie inne czynniki uznaje za nieistotne, a rolę dorosłego/nauczyciela w edukacji i otoczeniu dziecka marginalizuje. To nie sprzyja osiąganiu zmian ilościowych i jakościowych w rozwoju dziecka.

\section{Kompetencje pedagogiczne nauczyciela}

Praca nauczyciela podlega ciągłej ocenie: przez uczniów, ich rodziców, innych nauczycieli, przełożonych, społeczeństwo. Nauczyciel utożsamiany jest zawsze ze szkołą, a ona zarówno w literaturze naukowej, jak i publicystycznej opisywana jest często negatywnie. 
Krytyczną analizę praktyki szkolnej na poziomie edukacji wczesnoszkolnej zaprezentowały Klus-Stańska i Nowicka w książce „Sensy i bezsensy edukacji wczesnoszkolnej” na przykładzie edukacji polonistycznej i matematycznej. Autorki opisały specyficzny rytualizm w nauce czytania, pisania i mówienia, wymagania nauczyciela pozbawione logiki i związku z życiem, deklaratywność w działaniach twórczych i rozwijanie kompetencji wyłącznie na użytek szkolny. Wykonywanie w większości zadań zamkniętych, prostych, bez możliwości odnajdywania zależności w algorytmach, tworzenia twórczych rozwiązań. Autorki wskazały również na mit ekskluzywności i ludyczności w rozwijaniu kompetencji matematycznych dzieci. Opisały też bariery, które są niezależne od nauczyciela, tzw. inercję metodyczną, mistyfikację, zmiany modelu nauczyciela, zbiurokratyzowanie systemu edukacji (Klus-Stańska, Nowicka 2013).

Wiele czynników składa się na taki obraz, niejednokrotnie uwarunkowany sytuacją polityczną, społeczną, kulturową, a nie tylko samą osobą nauczyciela. W procesie edukacji ważne są kontakty indywidualne „nauczyciel - uczeń”, ale też szereg innych relacji, które nawiązywane są między samymi uczniami, zespołem uczniowskim i nauczycielem. Działalność indywidualna, wielopodmiotowa wymaga szerokiej wiedzy i umiejętności od nauczyciela, interpretacji procesu kształcenia i wychowania z punktu widzenia uprawnień i kompetencji pedagogicznych, jakie powinien posiadać.

Kompetencje, jak pisze Czerepaniak-Walczak (za Morrow, Torres), mają wymiar osobowy, podlegają rozwojowi, a właściwość tę, uwidaczniającą się w działaniu, człowiek osiąga poprzez wyuczenie (Czerepaniak-Walczak 2006: 128). Stanisław Dylak ujmuje kompetencje jako zdolność i umiejętność ludzi do realizowania określonych zadań, stanowiącą wypadkową wiedzy, umiejętności, motywacji, postaw, emocji i wartościowania (Dylak 1995: 37). Odnoszą się one do sytuacji pedagogicznych, w których uczestniczy nauczyciel i dotyczą sposobów porozumiewania się, twórczej, konstruktywnej pracy, działalności społecznej, rozwijania zdolności i zainteresowań. Świadomość wiedzy, odpowiedzialność i aktywność człowieka jest podstawą rozwoju kompetencji. Podmiot potrafi w sposób uprawniony wykorzystać je w celu realizacji działań. Opisanie kompetencji nauczycielskich jest trudne ze względu na specyfikę zawodu nauczyciela, jak zauważa Robert Kwaśnica, różnorodność specjalizacji nauczycielskich też nie sprzyja temu opisowi. Proponuje odnieść się do wybranych kompetencji i wyróżnia kompetencje praktyczno-moralne (interpretatywne, moralne, komunikacyjne) oraz kompetencje techniczne (postulacyjne, metodyczne, realizacyjne) (Śliwerski 2003: 300-301).

W zakresie kompetencji interpretatywnych autor wyróżnia takie właściwości, które umożliwiają rozumienie otaczającego świata, intepretowanie swojego stosunku do rzeczywistości i do innych ludzi, zadawanie pytań, podążanie za zmianami i krytyczną refleksję nad nimi. Prowadzenie refleksji moralnej, etyczne uprawomocnianie działań, ocena jakości własnego zachowania, zasad moralnych, postępowania wobec innych ludzi, szanowania ich prawa do wolności, do podmiotowości, do wyboru własnej drogi życiowej. Otwarcie na drugiego człowieka zawiera się w myśleniu dialogicznym, które uwidacznia się w empatycznym rozumieniu i akceptacji uczniów, zdolności do krytyki, jako 
wspólnego poszukiwania drogi porozumienia oraz przyjęcia postawy autonomii w wyrażaniu własnego punktu widzenia, osobistego, indywidualnego zdania, poglądu, oceny. Kompetencje komunikacyjne natomiast to zdolność do dialogu z sobą samym i z innymi ludźmi, stosowanie skutecznych sposobów porozumiewania się z każdym uczestnikiem sytuacji edukacyjnych (Śliwerski 2003: 300-301).

Kompetencje postulacyjne to umiejętność wyrażania instrumentalnie pojmowanych celów, umiejętność odtwarzania ich zgodnie z przyjętymi odgórnie założeniami, naśladowanie celów realizowanych przez innych lub ustalanie celów własnych, indywidualnych. Kompetencje metodyczne obejmują taką umiejętność, która umożliwia działanie według określonego porządku czynności. Stosowane metody gwarantują powtarzalność, skuteczność i efektywność w realizacji założonych celów. Wybór odpowiednich metod może być naśladowaniem pracy innych nauczycieli lub twórczym, kreatywnym, samodzielnym pomysłem. Kompetencje realizacyjne dotyczą organizacji i tworzenia warunków oraz doboru środków do realizacji założonych celów. Umiejętność organizowania przestrzeni klasy, łączenie z odpowiednimi formami pracy i stosowanie adekwatnych do realizacji programu nauczania materiałów i narzędzi decyduje o skuteczności pracy nauczyciela (Śliwerski 2003: 301).

W literaturze pedagogicznej autorzy różnych podziałów obszarów kompetencji związanych z zawodem nauczyciela wskazują, że propozycje te nie mają charakteru skończonego, zamkniętego. Robert Kwaśnica wskazuje jednak na hierarchię ważności kompetencji i za nadrzędne w zawodzie nauczycielskim uznaje kompetencje praktyczno-moralne odpowiadające z swoistość pracy nauczycielskiej (Śliwerski 2003: 303-304). Zmieniająca się rzeczywistość stawia wymagania zarówno uczniom, jak i nauczycielom.

\section{Ustalenia metodologiczne}

Celem prezentowanych badań jest rozpoznanie rodzaju i zakresu kompetencji studentów edukacji wczesnoszkolnej niezbędnych do wykonywania zawodu nauczyciela. Problem sformułowano w postaci pytania: Jaki rodzaj i zakres kompetencji praktyczno-moralnych i technicznych uświadamiają sobie studenci edukacji wczesnoszkolnej? W badaniu kompetencji zastosowano metodę sondażową i metodę wywiadu kwestionariuszowego, jako wspierającą. W badaniach sondażowych wykorzystano kwestionariusz kompetencji pedagogicznych studenta opracowany przez Pankowską (Pankowska 2008: 147). Badania prowadzono w okresie luty - marzec 2014 r., objęto nimi 50 studentów trzeciego roku edukacji wczesnoszkolnej studiów pierwszego stopnia Elbląskiej Uczelni Humanistyczno-Ekonomicznej i Państwowej Wyższej Szkoły Zawodowej w Elblągu.

\section{Analiza wyników badań}

Tworzenie i definiowanie pojęć, opisywanie faktów, zjawisk to umiejętności kształtowane, rozwijane w toku studiów. Studenci zostali poproszeni o sformułowanie definicji kompetencji pedagogicznych i opisali je następująco: zdolności, umiejętności do pracy 
z dziećmi; odpowiednie umiejętności i wiedza, jaka powinien posiadać nauczyciel; sa to obowiązki, wiedza i odpowiedzialność; wiedza, umiejętności i przygotowanie do pracy jako pedagog. W większości podanych stwierdzeń pojawia się kategoria wiedzy i umiejętności, jako najważniejszych i niezbędnych w zakresie kompetencji pedagogicznych.

Część definicji podkreśla miejsce i czas zdobywania kompetencji: sq to nabyte umiejętności i wiedza w trakcie studiów, po czym sa realizowane w pracy; umiejętności, wiadomości, wiedza, które zdobywa się podczas studiów, pracy, najczęściej przez doświadczenie; wiedzę zdobywa się na przedmiotach, umiejętności na praktykach, a potem to już $w$ czasie pracy $w$ szkole najbardziej się doskonali. Wielu badanych podkreśla, że rozwijanie i doskonalenie kompetencji następuje poprzez zdobywanie doświadczenia w pracy zawodowej. Studenci w definiowaniu kompetencji pedagogicznych mają świadomość, że do ich ukształtowania potrzebne jest doświadczenie, ale też pewne tzw. predyspozycje osobowe: jest to coś, co nabywa się wraz z doświadczeniem, ale nie tylko, z niektórymi można się urodzić; gotowość do uczenia; trzeba znać rozwój dzieci, widzieć ich dobro i być cierpliwym; nauczyciel musi uczyć się całe życie.

Badani studenci odbyli już ciągłą praktykę nauczycielską, posiadają wynikające z niej niewielkie doświadczenie w pracy z dziećmi w szkole. Mają też swoje spostrzeżenia dotyczące użyteczności wiedzy i umiejętności zdobytych $\mathrm{w}$ trakcie studiów. W wywiadzie na pytanie: Które z kompetencji uważasz za najważniejsze w pracy nauczyciela i dlaczego? pojawiały się następujące odpowiedzi: uważam kompetencje interpersonalne, ponieważ nauczyciel powinien z łatwościa nawiazywać i utrzymywać dobre relacje z uczniami, rodzicami, jak również z pracownikami danej placówki; dydaktyczno-wychowawcze, ponieważ dzięki nim nauczyciel jest $w$ stanie zachować dyscyplinę; umiejętności praktyczne $i$ dydaktyczne, nauczyciel musi wiedzieć jak prowadzić zajęcia i znać metody jak to zrobić; umiejętność dobrej organizacji konkretnych lekcji, przekazywanie wiedzy uczniom w ciekawy sposób, przygotowanie do zajęć; umiejętność zainteresowania dzieci zajęciami, by nie nudzity się na nich i w jak najlepszym stopniu przyswoily wiedzę; umiejętne podejście do dzieci, organizowanie pracy na lekcjach, aby w ciekawy sposób przekazać im informację i sprawić, by szkoła nie była „przymusem”. W określaniu najważniejszych studenci rzadko określają konkretne rodzaje kompetencji, przyjmując podział konkretnego autora, pojawiają się jednak takie kategorie, jak: umiejętności metodyczne, bogata wiedza ogólna, umiejętność nawiązywania relacji, umiejętność organizowania zajęć. W wypowiedziach podają zakresy różnych rodzajów kompetencji, które poznawali w toku studiów, podczas zajęć i uważają, że w pracy nauczyciela najważniejsze są, przyjmując podział R. Kwaśnicy, kompetencje metodyczne, realizacyjne, komunikacyjne. Natomiast część studentów zakres kompetencji interpretatywnych i moralnych identyfikuje z posiadanymi cechami osobowymi nauczyciela lub określonym światem wartości. I tak studenci wymieniali: sprawiedliwość (każdy z pedagogów powinien uczciwie oceniać), wiedza (jest niezbędna), punktualność, kreatywność, pracowitość, dyscyplina, poczucie humoru; sumienność, punktualność, inteligencja, wiedza, uczciwość, sprawiedliwość, konsekwencja, dyscyplina, otwartość (...), ale też madrość (̇̇eby przekazać wiedze), sprawiedliwość (obiektywnie oceniać), cier- 
pliwość, kreatywność, punktualność, pozytywne nastawienie. Niektóre z tych, uznanych przez studentów kompetencji, można przypisać nie tylko nauczycielom, ale każdej innej grupie zawodowej. Może studenci nie widzą potrzeby różnicowania rodzajów kompetencji pedagogicznych od innych zawodowych. Dla porównania niżej zaprezentowano analizę wyników badań sondażowych dotyczących zakresów konkretnych rodzajów kompetencji pedagogicznych, które uświadamiali sobie i deklarowali badani studenci.

1. Kompetencje interpretatywne. Swoją wiedzę na temat metod, form dobrze ocenia więcej niż połowa badanych (54\%) i deklaruje, że potrafi ją interpretować, dostosowywać do rzeczywistości, zmieniać. Studenci mają świadomość, na czym polega praca szkoły, jej zadania i organizacja jako instytucji (72\%), właściwie interpretują też warunki efektywnego, skutecznego nauczania (62\%), a w zakresie pracy wychowawczej w klasie $78 \%$ badanych studentów deklaruje wiedzę wystarczającą do organizowania i prowadzenia procesu wychowawczego.

2. Kompetencje moralne. Znajomość proces wychowania i jego uwarunkowań deklaruje większości badanych studentów (90\%). Tyle samo badanych ma świadomość własnych poglądów na temat wychowania. W zakresie pracy nad poczuciem własnej wartości i akceptacji uczniów 76\% badanych deklaruje, że posiada umiejętności oddziaływań, co piąty badany ocenia, że takich umiejętności nie posiada. Praca nad sobą i własnym rozwojem to ważny aspekt osobowy każdego człowieka. Umiejętność tę deklaruje $90 \%$ badanych studentów.

3. Kompetencje komunikacyjne. Umiejętność podejmowania i prowadzenia dialogu z uczniami na różne tematy wychowawcze deklaruje $72 \%$ badanych, a $98 \%$ uznaje, że dobrze porozumiewa się z ludźmi. Umiejętność motywowania do nauki i zainteresowania uczeniem innych w sposób zdecydowany deklaruje 10\%, niepewnych w swoich działaniach natomiast jest 70\% studentów. Niepewni są również (54\%) sytuacji związanych z utrzymaniem dyscypliny podczas prowadzenia zajęć. Pozostali studenci nie uświadamiają sobie zakresu swoich kompetencji komunikacyjnych.

4. Kompetencje postulacyjne. Zdecydowane przyjęcie perspektywy nauczyciela w spojrzeniu na szkołę i proces nauczania deklaruje prawie co piąty badany, $46 \%$ ma świadomość trudności realizacji tej perspektywy. Działanie ukrytego programu i skutków, jakie powoduje w środowisku szkolnym, uświadamia sobie $24 \%$, dla $68 \%$ badanych jest to raczej mało znany zakres zagadnienia. Dobry i efektywny nauczyciel realizuje program i jest lubiany przez uczniów, to deklaracja $20 \%$ studentów, wiedzę, jak postępować, żeby być takim nauczycielem, oceniają pozytywnie. Niepewnych co do posiadania umiejętności takiego zachowania jest zdecydowana większość ( $80 \%$ badanych).

5. Kompetencje metodyczne. Wiedzę i umiejętności w zakresie przygotowania się nauczyciela do prowadzenia zajęć deklarują wszyscy badani. Większość (70\%) uświadamia sobie korzyści stosowania metod poznawania uczniów i klasy jako zespołu, ale w kontaktach z innymi, w działaniach publicznych zdecydowaną postawę wyraża tylko $16 \%$, a niezdecydowanych jest $76 \%$ studentów. Pozostali nie uświadamiają sobie zakresu tego rodzaju kompetencji. 
6. Kompetencje realizacyjne. Kompetencje realizacyjne odnoszą się do wiedzy i umiejętności w zakresie doboru środków i tworzenia warunków właściwej organizacji procesu kształcenia, adekwatnie do wyznaczonych celów. Wiedzę na temat różnych form nauczania zdecydowanie deklaruje 34\% studentów, 54\% wyraża niepewność. W zakresie organizacji procesu kształcenia, tworzenia warunków do prezentacji materiału - tylko 18\% dobrze ocenia swoją wiedzę i umiejętności; $64 \%$ uważa wiedzę i umiejętności w tym obszarze za niepełne. Dobór właściwych środków to również ocenianie, nagradzanie. Umiejętność obiektywnego oceniania deklaruje jedna piąta badanych, wątpliwości posiada $60 \%$, brak umiejętności wyraża również jedna piąta badanych.

\section{Wnioski}

1. Studenci edukacji wczesnoszkolnej mają świadomość pojęcia kompetencji pedagogicznych i definiują je jako: wiedza i umiejętności, miejsce i czas ich zdobywania, a także pewne predyspozycje osobowe.

2. Studenci najczęściej konkretne rodzaje kompetencji określają poprzez cechy osobowe nauczyciela lub przyjęty świat wartości, a także ogólne umiejętności metodyczne, sposób organizowania zajęć, nawiązywania relacji i wiedzę.

3. Najwięcej studentów deklaruje, że posiada wiedzę i umiejętności w zakresie kompetencji interpretatywnych i moralnych.

4. W zakresie kompetencji komunikacyjnych najwięcej studentów jest świadomych, że mają trudności w obszarze motywowania, przekonywania do nauki i zainteresowania uczeniem innych, natomiast większość deklaruje umiejętność prowadzenia mowy dialogowej.

5. W zakresie kompetencji postulacyjnych studenci deklarują najmniej wiedzy i umiejętności. Nie znają działań ukrytego programu i skutków, jakie powoduje, trudne dla nich jest spojrzenie na szkołę i proces nauczania z perspektywy nauczyciela. Wydaje się, że ten zakres kompetencji nabywa się podczas pracy, zdobywania doświadczeń zawodowych, dobrej znajomości środowiska uczniów i szkoły jako instytucji.

6. W zakresie kompetencji metodycznych wszyscy studenci zdecydowanie dobrze oceniają przygotowanie do prowadzenia zajęć, jednocześnie prawie wszyscy deklarują w kontaktach i działaniach publicznych niezdecydowaną postawę.

7. W zakresie kompetencji realizacyjnych wiedzę i umiejętności deklaruje najmniej studentów. Zdecydowana większość nie uświadamia sobie kompetencji w zakresie organizacji procesu kształcenia w odniesieniu do wyznaczonych celów, oceniania. Mają wątpliwości co do posiadanej wiedzy i umiejętności. Jest to kolejny rodzaj kompetencji pedagogicznych, który najczęściej potwierdza doświadczenie w pracy zawodowej. Analiza wyników badań pozwala na stwierdzenie, że studenci kończący studia pedagogiczne różnie uświadamiają sobie zakres i rodzaj posiadanych kompetencji pedagogicznych. Zauważalna jest orientacja praktyczna, charakterystyczna dla młodego nauczyciela 
z niewielkim doświadczeniem. Deklaracja dobrego przygotowania do zajęć nie gwarantuje dobrej organizacji procesu kształcenia, określania celów i oceny postępów rozwojowych dzieci, postrzeganych perspektywicznie. Jednak wydaje się, że ten kierunek rozwoju kompetencji jest dobry dla budowania strategii rozwojowych uczniów. Reakcja na zmieniające się potrzeby społeczne (np. uczniów i ich rodziców), rozumienie zmian kulturowych, wypracowanie własnej koncepcji kształcenia, integracja wiedzy, umiejętności, postaw, poglądów, konstruowania i rekonstruowania sytuacji edukacyjnych jest możliwa w ciągu wieloletniego rozwoju zawodowego. Wysokie wymagania stawiane nauczycielowi w obszarze kompetencji pedagogicznych są warunkiem zmiany rozwojowej uczniów, podjęcia odpowiedzialności za ich poznawczy, psychospołeczny rozwój w wymiarze indywidualnym oraz osiąganie osobistych sukcesów.

\section{Literatura}

Bruner J. (1971), O poznawaniu - szkice na lewa rękę. Warszawa, PIW.

Czerepaniak-Walczak M. (2006), Pedagogika emancypacyjna. Gdańsk, GWP.

Dauber H. (1997), Podstawy pedagogiki humanistycznej. Kraków, Oficyna Wydawnicza Impuls.

Dolya G. (2007), Klucz do uczenia się. Technologia rozwoju dziecka. Key to Learning Polska.

Dylak S. (1995), Wizualizacja w kształceniu nauczycieli. Poznań, UAM.

Jaworska T., Leppert R. (red.) (2001), Wprowadzenie do pedagogiki. Kraków, Oficyna Wydawnicza Impuls.

Klus-Stańska D., Nowicka M. (2013), Sensy i bezsensy edukacji wczesnoszkolnej. Gdańsk, Harmonia.

Klus-Stańska D. (2009), Rozwojowa zmiana poznawcza. W: Klus-Stańska D., Szczepska-Pustkowska M. (red.), (2009), Pedagogika wczesnoszkolna - dyskursy, problemy, rozwiazania. Warszawa, WAiP.

Klus-Stańska D. (2009a), Dyskursy pedagogiki wczesnoszkolnej. W: Klus-Stańska D., Szczepska-Pustkowska M. (red.), (2009), Pedagogika wczesnoszkolna-dyskursy, problemy, rozwiazania. Warszawa, WAiP.

Kozielecki J. (1980), Koncepcje psychologiczne człowieka. Warszawa, PIW.

Pankowska D. (2008), Pedagogika dla nauczycieli w praktyce. Kraków, Oficyna Wydawnicza Impuls.

Przetacznik-Gierowska M., Tyszkowa M. (2003), Psychologia rozwoju człowieka. Warszawa, PWN.

Śliwerski B. (2012), Pedagogika ogólna. Podstawowe prawidłowości. Kraków, Oficyna Wydawnicza Impuls.

Śliwerski B., Kwieciński Z. (red.) (2003), Pedagogika. Podręcznik akademicki. T. 2. Warszawa, PWN.

Wygotski L.S. (1978), Narzędzie i znak w rozwoju dziecka. Warszawa, PWN.

www.fokus.pl,2011(człowiek)kto-wychowujetwoje-dziecko-6148?strona=1 [23.03.2015].

www.simplypsychology.org/zone-of-Proximal-Development.html [23.03.2015].

www.theguardian.com/science/2012/oct/14/childhool-stimulation-key-brain-development [14.07.2014]. 